\title{
Spatial Fluctuations in Zooplankton Biotypes of the Imo River in a Niger Delta Area of Nigeria
}

\author{
Dike Henry Ogbuagu ${ }^{1, *}$, Adedolapo Abeke Ayoade ${ }^{2}$ \\ ${ }^{1}$ Department of Environmental Technology, Federal University of Technology, PMB 1526, Owerri, Nigeria \\ ${ }^{2}$ Department of Zoology, University of Ibadan, Nigeria \\ henrydike2002@yahoo.com
}

\begin{abstract}
The study identified zooplankton biotypes of the increasingly in-stream sand-mined Imo River in Etche, a Delta area of Nigeria, as indicators of the health of the aquatic ecosystem. Plankton samples were collected with a $55 \mu \mathrm{m}$ mesh size plankton net that was hauled horizontally along the river course for 5 minutes at 7 sampling locations once monthly for 24 months (March 2007-February 2009). Samples were fixed/preserved in 4\% formalin solution in labelled plastic containers. In the laboratory, a wide-mouthed pipette was used to withdraw $1 \mathrm{ml}$ of the plankton subsample and to place it on a Sedge-wick rafter-counting chamber. Standard keys were used for species identifications and counts made through direct microscopy. The ANOVA, post-hoc plots of group means, hierarchical cluster analysis (HCA), and the Margalef's species diversity index were used to analyze data. Zooplankton had low diversity index $(0.926 \pm 0.100)$ and was made up of 7 taxa and a mean density of 433 organisms $/ \mathrm{ml}$; with order of dominance as Cladocera $(25.87 \%)>$ Copepoda $(20.55 \%)>$ Protozoans $(19.17 \%)>$ Rotifera $(18.71 \%)>$ fish eggs and larvae $(9.24 \%)>$ Crab larvae $(4.62 \%)>$ Beetle larvae $(0.69 \%)$. Plankton abundance peaked in sampling location 1 (140 organisms $/ \mathrm{ml} ; 32.41 \%)$ and was least in location $3(21$ organisms $/ \mathrm{ml} ; 4.86 \%)$, even as there was marked spatial heterogeneity in the taxa composition $\left[\mathrm{F}_{(11.94)}>\mathrm{F}_{\text {crit(3.94) }}\right]$ at $\mathrm{P}<0.05$. The HCA revealed that crab larvae, fish eggs and larvae, beetle larvae, and copepods formed the first and richest cluster, while the rotifers, cladocerans and protozoans formed the sparse $2^{\text {nd }}, 3^{\text {rd }}$ and $4^{\text {th }}$ clusters, respectively. The low biotic diversity recorded could be attributed to growth-limiting perturbations created by ongoing in-stream sand mining in water columns.
\end{abstract}

Keywords Imo River, Etche Local Government Area, Plankton biotypes, Biotic index, In-stream Sand Mining

\section{Introduction}

Etche, one of the 23 Local Government Areas (LGAs) of Rivers State in Nigeria has three major rivers- Imo, Otamiri-Oche and Oge-Ochie rivers. Of these, the Imo River, which rises from the Okigwe/Awka uplands in the neighbouring Imo State, is the major and most extensive. In the LGA, the Imo River confluences first with the Oge-Ochie at Nihi, and later with the Otamiri-Oche at Umuebulu.

According to the NADECO[1] and Mogo[2], it is one of the independent straight rivers of the Niger Delta and in the larger Rivers State, the river courses through Etche, Oyigbo, Khana, Opobo/Nkoro and Andoni LGAs, before emptying into the Atlantic Ocean. The regime of the upper and middle courses of the river is alluvial while the lower course is subjected to tidal movements[3].

Due to increasing urbanization activities attendant to the exploration and exploitation of oil and gas in the area, in-stream sand mining by local inhabitants has become a

* Corresponding author:

henrydike2002@yahoo.com (Dike Henry Ogbuagu)

Published online at http://journal.sapub.org/ije

Copyright (C) 2012 Scientific \& Academic Publishing. All Rights Reserved common occupation, serving the many road constructions and building of houses in the area. Other than the benefits derivable from inland sand mining, alteration of hydrological regimes, loss of wetland and floodplains, sediment suspension and increased turbidity are some ecosystem imbalances that could impact negatively on the flora and fauna of aquatic ecosystems[4-9]. According to Spaak and Bauchrowitz[10] and Ogbuagu et al.[11], the impacted resident organisms include algae, macrophytes, protozoa, fish, and other animals.

While some of these impacted flora and fauna could provide a general indication of resultant water pollution, others could enable the direct tracking of pollution sources. Of these, plankton[which occupy the base level of food chains that lead up to commercially important fisheries] have severally been used as ideal theoretical and experimental candidates for population ecology studies of water quality[12] due to their small sizes, short generation time and a relatively homogenous habits. Additionally, plankton communities play a major role in the biogeochemical cycles of many important elements such as the carbon cycle, nitrification, denitrification, remineralization and methanogenesis. These cycles bring about such processes as primary production and recycling. It is against these relevancies and for the need to 
establish the status of this segment of the river under anthropogenic perturbation that the current study undertook the use of zooplankton biotypes as fundamental indicators of pollution.

\section{Material and Methods}

\subsection{Study Area}

Etche, a subsistent agrarian ethnic group in the Niger delta of Nigeria is located between longitude $06^{\circ} 05^{\prime}$ and $07^{\circ} 14^{\prime} \mathrm{E}$ and latitude $05^{\circ} 08^{\prime}$ and $04^{\circ} 45^{\prime} \mathrm{N}$ (Figure 1). The climate is typical of the tropical rainforest zone and rainfall is between $160-236 \mathrm{~cm}$; with about 300 rain days especially during March-November periods. Temperature ranges between 24 and $38^{\circ} \mathrm{C}$, and the predominant wind direction is Northerly winds, although there is a significant influence from the Southerly winds. Highest humidities of up to $90 \%$ are usually recorded during the wet season while values as low as $40 \%$ could be recorded at the peak of the dry season[13]. However, some inhabitants also engage in petty trading, palm wine tapping, fishing, hunting and sand mining. In the neighborhoods of majority of the sampling locations are ongoing oil exploitation activities by the Shell Petroleum Development Company of Nigeria (SPDC), whose activities dates back to 1958 when crude oil was first discovered in the ethnic area.

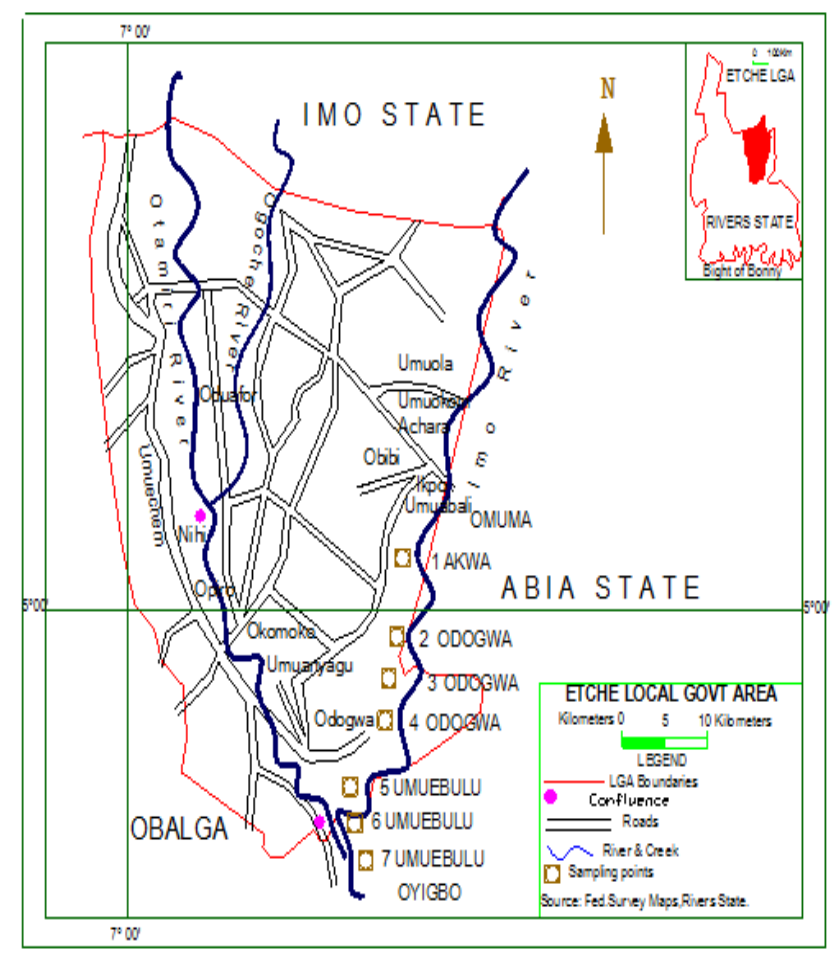

Figure 1. Map of Etche LGA showing the sampling locations along Imo River

\subsection{Sampling Design and Locations}

Sampling for plankton were done once monthly for 24 months (March 2007-February 2009) at 7 sampling locations.
Sand mining activities by local operators as well as other human activities such as washing of cloths and bathing were ongoing at all the sampling locations (though sand mining only commenced during the second year in location 1). Sampling location 1 was situated upstream at Akwa community. Sampling locations 2, 3, and 4 were situated about 1 $\mathrm{km}$ apart at Odogwa community; with location 2 situated about $2 \mathrm{~km}$ from 1 . Locations 5, 6, and 7 were also situated about $1 \mathrm{~km}$ apart at Umuebulu community; with location 5 situated about $3 \mathrm{~km}$ from 4 . Odogwa and Umuebulu communities house oil and gas facilities belonging to the SPDC.

\subsection{Sample Collection}

From a locally made canoe used for transportation, plankton net of $55 \mu \mathrm{m}$ mesh size was hauled horizontally along the river course for 5 minutes at each sampling location according to the methods of Grant[14] and Anene[15]. The resultant concentrated plankton samples were later transferred to plastic containers, fixed and preserved in $4 \%$ formalin solution according to Boney[16] and Anene[15] in the field.

\subsection{Laboratory Analysis}

In the laboratory, with the use of a wide-mouthed pipette, $1 \mathrm{ml}$ of the plankton subsample was withdrawn from the field samples that had been homogenized by inverting the containers few times, placed on a Sedge-wick rafter-counting chamber and observed by direct microscopy. Keys provided by Whitford and Schumacher[17], Needham and Needham[18], Cole[19], Maosen[20], Jeje and Fernando[21,22], Egborge[23], and APHA[24] were used for species identifications. Counts were made in triplicates and their averages taken and expressed as organisms $/ \mathrm{ml}$ of water.

\subsection{Statistical Analyses}

The test of homogeneity in mean variance of the plankton taxa across the sampling locations was made with the single factor analysis of variance (ANOVA) and post-hoc plots of group means was made with means plots. The hierarchical cluster analysis (HCA) was used to explore and reveal natural groupings (or clusters) within the plankton assemblages that would otherwise not be apparent. Species diversity was determined with the Margalef's index (I)[25].

\section{Results}

\subsection{Taxa Composition and Abundance}

A total of 433 zooplankton organisms $/ \mathrm{ml}$, made up of 7 taxa were identified. The cladocerans consisted a total of 112 organisms $/ \mathrm{ml}$ from 5 genera, thus making up the largest percentage of $25.87 \%$ of the zooplankton biotypes. The species included Alonella rostrata, Bosmina longirostris, Chydorus gibbus, Daphnia hyalins and D. carinata (Appendix 1). The copepods consisted 4 genera made up of 89 organisms $/ \mathrm{ml}(20.55 \%)$. The common species included 
Canthocamptus staphylinus, C. carinetus, Paracyclops finibriatus, Limnocalanus macrurus and Senecella calanoides. Other than the cladocerans and copepods, the other crustacean zooplankton (crab larvae) comprised 20 organisms $/ \mathrm{ml}(4.62 \%)$, while the piscean fish eggs and larvae consisted 40 organisms $/ \mathrm{ml}(9.24 \%)$. The coleopteran beetle larvae consisted 3 organisms $/ \mathrm{ml}(0.69 \%)$ while the rotifers consisted 81 organisms $/ \mathrm{ml}$ (18.71\%). Common rotifer species were Colurella spp., Keratella valga and Branchionus forficula. However, the protozoans consisted 3 genera that were made up of 83 organisms $/ \mathrm{ml}$ (19.17\%), with common species as Arcella arenaria, Didinium bolbianii and Peridinium bipes. The order of numerical abundance of the zooplankton taxa was Cladocera $>$ Copepoda $>$ Protozoans $>$ Rotifera $>$ fish eggs and larvae $>$ Crab larvae $>$ Beetle larvae.

\subsection{Spatial Abundance}

The highest zooplankton abundance of 140 organisms $/ \mathrm{ml}$ $(32.41 \%)$ was recorded in sampling location 1 while sampling location 3 recorded the least abundance of 21 organisms $/ \mathrm{ml}(4.86 \%)$. The spatial order of numerical abundance of the zooplankton biotypes identified was SL 1> SL $7>$ SL $2>$ SL $4>$ SLs $5 \& 6>$ SL 3.

Of the Cladocera, Copepoda and Crab larvae, highest numerical abundances of 49,31 and 7 organisms $/ \mathrm{ml}$ respectively were recorded in SL 1, while least count of 5 organisms $/ \mathrm{ml}$ and 1 organism $/ \mathrm{ml}$ were recorded in SL 3 and SL 6 for the cladocerans and copepods, respectively. Crab larvae was absent in SLs 3 and 5 (Figure 2).

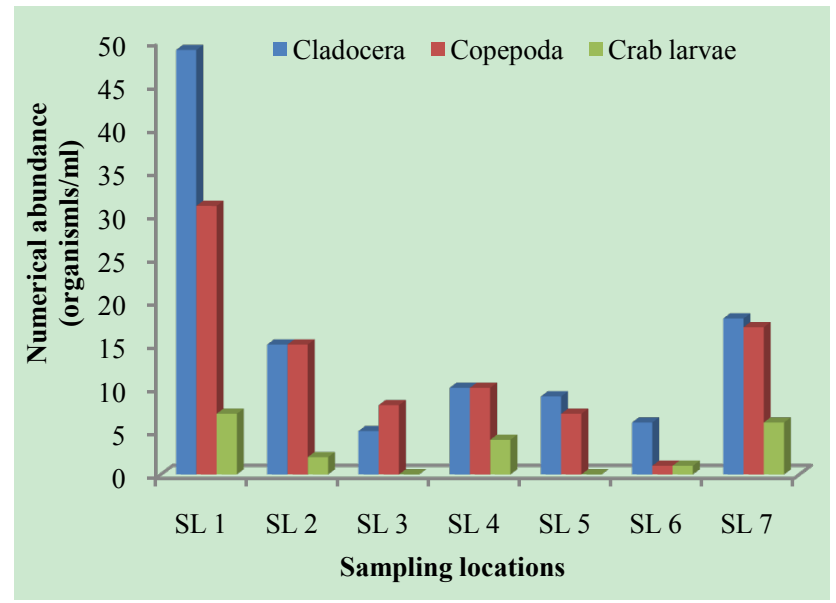

Figure 2. Spatial variations in Cladocera, Copepoda and crab larvae densities in Imo River in Etche LGA

Highest numerical abundances (12 and 2 organisms $/ \mathrm{ml}$ ) were also recorded in SL 1 for fish eggs and larvae and beetle larvae, respectively (Figure 3), while SL 3 and SLs 2, 4, 5, $6 \& 7$ recorded no fish eggs \& larvae and beetle larvae, respectively. However, highest abundances of 28 and 11 organisms $/ \mathrm{ml}$ were recorded in SL 1, and least abundances of 3 and 4 organisms $/ \mathrm{ml}$ were recorded in SL 3 for the rotifers and protozoans, respectively (Figure 4).

The test of homogeneity in mean variance of the plankton biotypes revealed significant spatial inequality $\left[\mathrm{F}_{(11.94)}>\right.$
$\left.\mathrm{F}_{\text {crit(3.94) }}\right]$ at $\mathrm{P}<0.05$. Further post-hoc means plots that utilized SL 1 as predictor variable revealed that the copepods (31) and cladocerans (49) (Figure 5), protozoans (11) and copepods (31) (Figure 6), copepods (31) and cladocerans (49) (Figure 7), protozoans (11) and cladocerans (49) (Figure 8), protozoans (11) (Figure 9), as well as protozoans (11) and cladocerans (49) (Figure 10) were most responsible for the observed spatial inequality in SLs 2, 3, 4, 5, 6 and 7, respectively.

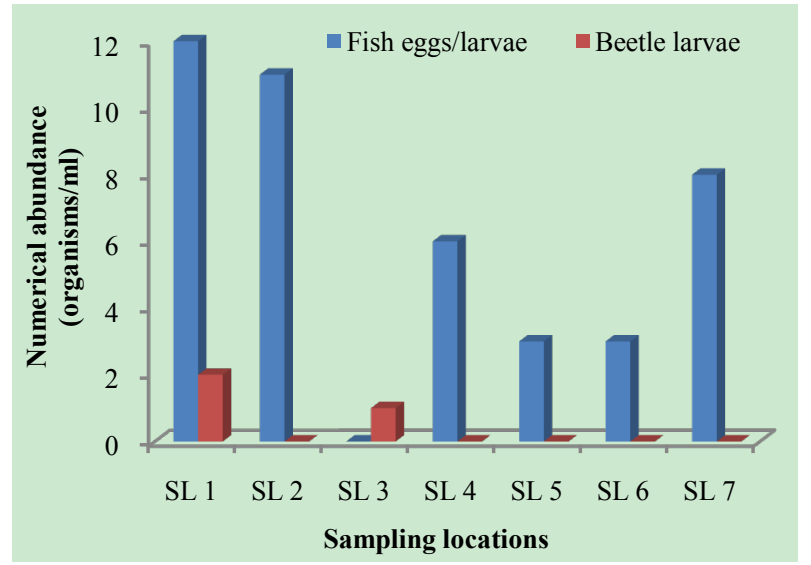

Figure 3. Spatial variations in fish eggs/larvae and beetle larvae densities in Imo River in Etche LGA

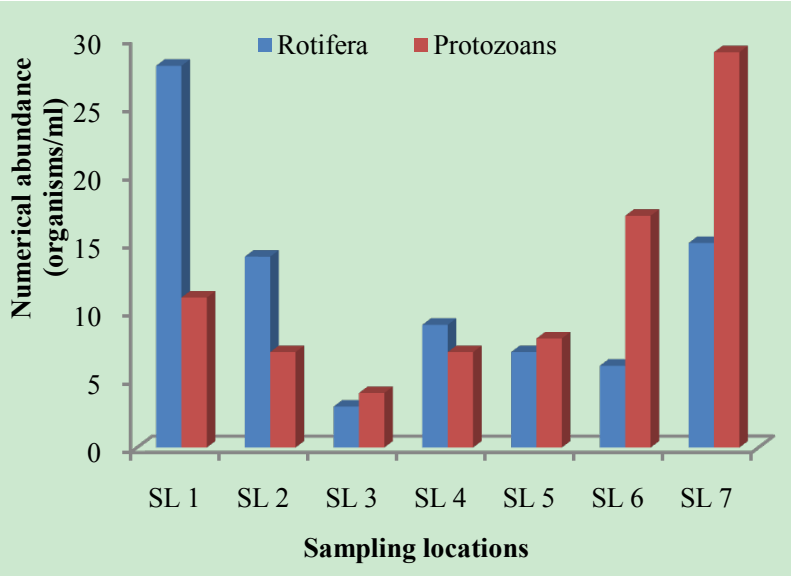

Figure 4. Spatial variation in rotiferan and protozoan densities in Imo River in Etche LGA

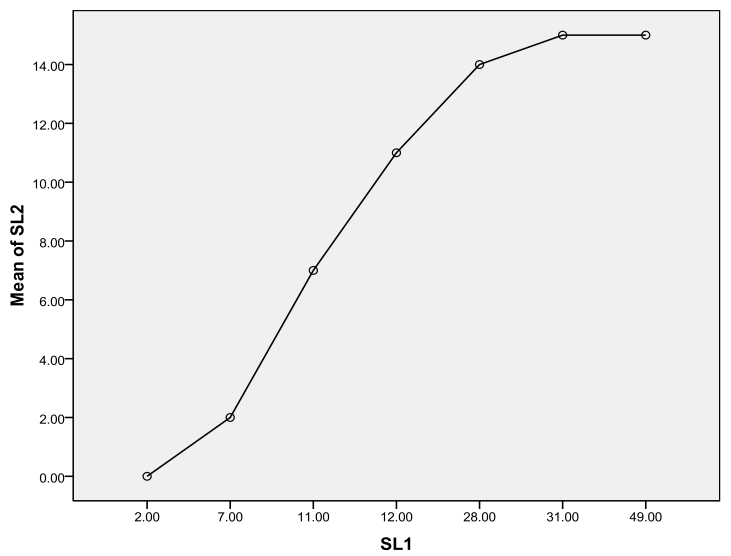

Fiure 5. Means plot of zooplankton abundance between SL 1 and SL 2 in Imo River in Etche LGA 


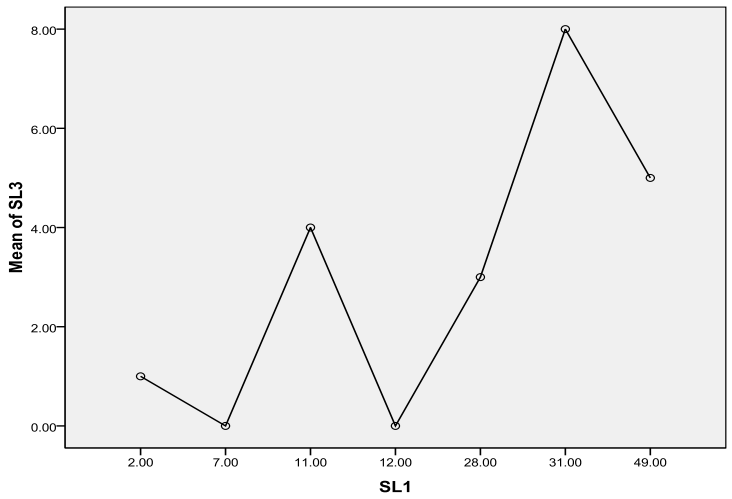

Figure 6. Means plot of zooplankton abundance between SL 1 and SL 3 in Imo River in Etche LGA

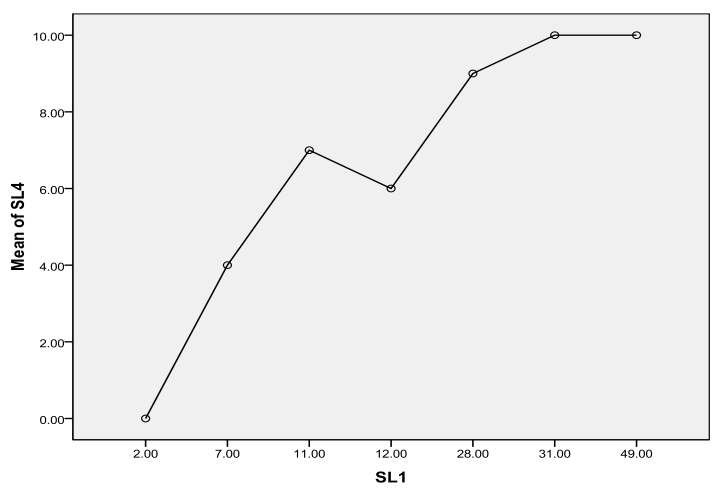

Figure 7. Means plot of zooplankton abundance between SL 1 and SL 4 in Imo River in Etche LGA

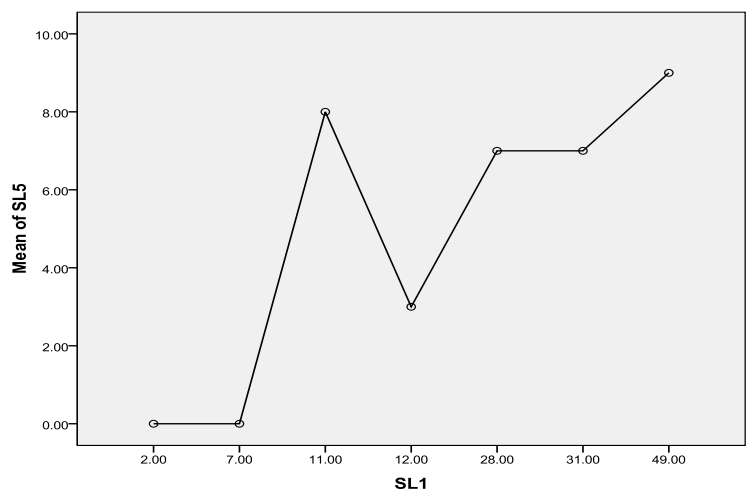

Figure 8. Means plot of zooplankton abundance between SL 1 and SL 5 in Imo River in Etche LGA

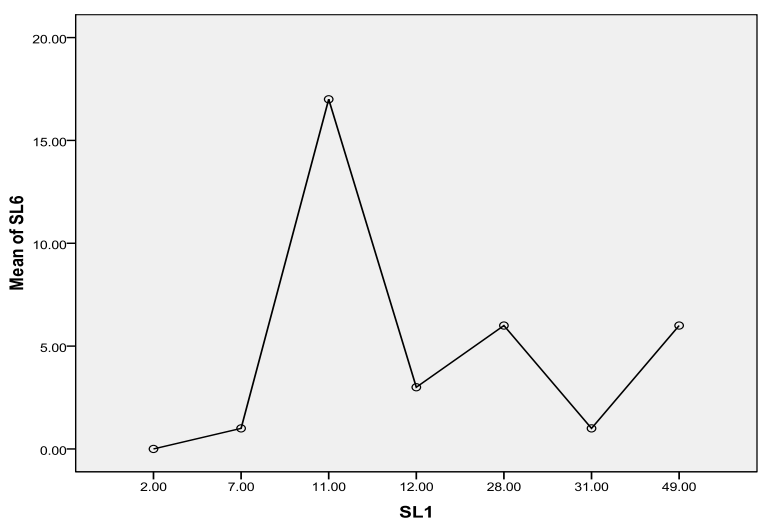

Figure 9. Means plot of zooplankton abundance between SL 1 and SL 6 in Imo River in Etche LGA

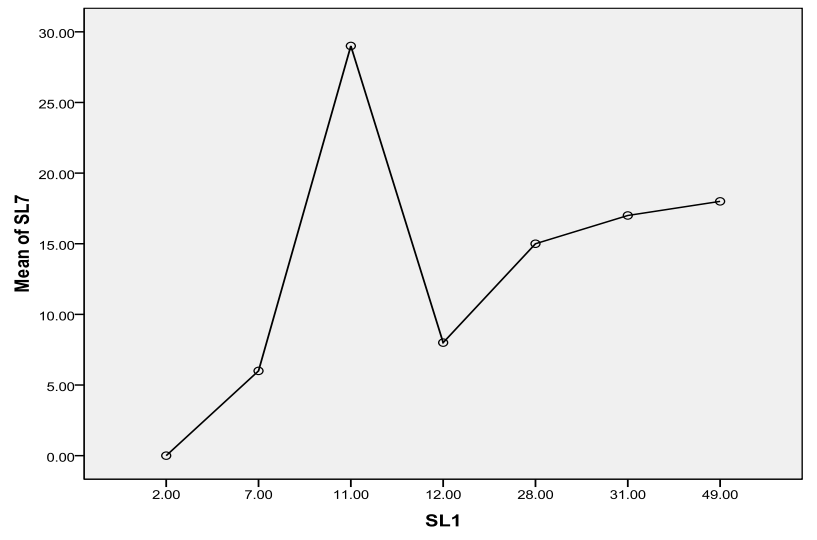

Figure 10. Means plot of zooplankton abundance between SL 1 and SL 7 in Imo River in Etche LGA

\subsection{Biotic Diversity Index}

Zooplankton biotypes recorded Margalef's Diversity Index (I) ranging from 0.000-3.641; with sampling location 1 again, exhibiting overall highest mean diversity of $1.866 \pm$ $1.300(29.00 \%)$, while location 3 exhibited least mean diversity of $0.348 \pm 0.000(5.00 \%)$ (Figure 11). SLs 3, 4, 5 \& 6 showed several zero zooplankton diversity than the rest of the locations during the study period. The order of magnitude of spatial diversity was SL $1>$ SL $7>$ SL $2>$ SL $4>$ SL $6>$ SL $5>$ SL 3.

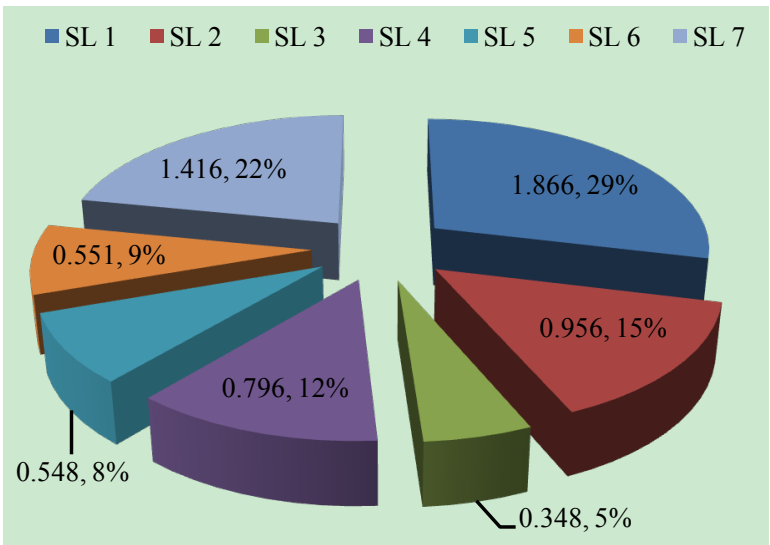

Figure 11. Mean spatial diversity of zooplankton of Imo River in Etche LGA

\subsection{Hierarchical Cluster Analysis (HCA)}

The coefficient column of the complete linkage HCA classification revealed a precise classification into four major clusters, as confirmed by the dendrogram (Figure 12). The clusters occurred in stages 19 and 20,20 and 21,21 and 22, and 22 and 23. The first cluster, with richer plankton abundance and diversity contained crab larvae, fish eggs and larvae, beetle larvae, and the copepods. The second and third clusters contained the lone rotifers and cladocerans each, while the last cluster contained the lone protozoans.

\section{Discussion}

\subsection{Plankton Abundance and Distribution}


The multiple effects of natural or altered conditions on plankton dynamics and compositions in aquatic environment have been emphasized by several authors, including Eze[26], Chattopadhyay and Barik[27] and Altaf et al.[28]. When compared with the works of Rai et al.[29] and Egborge[23] in other rivers, the Imo River in Etche LGA recorded comparatively lower zooplankton abundance and diversity. This paucity could be attributed to environmental perturbations (as also observed elsewhere by Armitage et al.,[30, 31]; Ogwejifor,[32] and EPA,[33]), especially arising from ongoing intense in-stream sand mining by local inhabitants which causes episodic high turbidity and depletion of nutrients in the river sediments thus, leading to decreased plankton abundance and productivity.

The health of the biotic community of any aquatic system is a function of the abundance and diversity of plankton as primary producers. In their study in March and October of 2003 in the segment of the Imo River in the nearby Oyigbo LGA, Zabbey et al.[34] recorded a total of 23 genera of zooplankton, and elsewhere in the Ologe Lagoon in South-western Nigeria, Okogwu and Ugwumba[35] recorded 21 genera of zooplankton.

Dendrogram using Complete Linkage

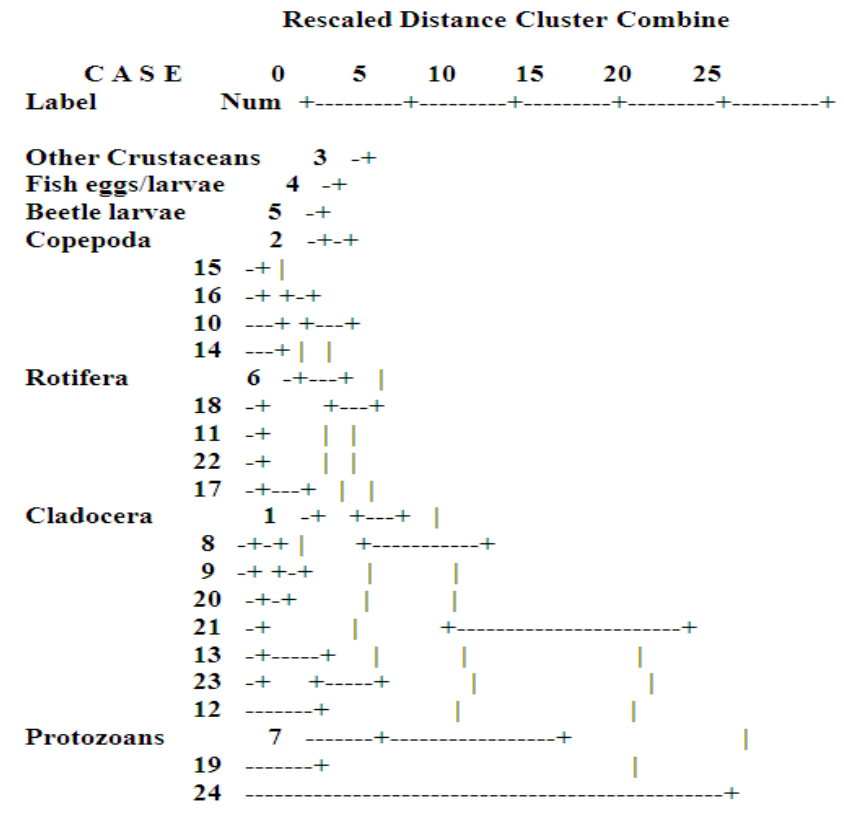

Figure 12. Dendrogram showing hierarchical clustering of zooplankton in Imo River in Etche LGA

Whereas the current study recorded only 19 zooplankton genera comprising 21 species, Chattopadhyay and Barik[27] recorded as high as 32 genera consisting of 34 species in a tropical freshwater in Krishnasayer, India.

The qualitative (not quantitative) order of dominance of the zooplankton biotypes (Cladocera $>$ Copepoda $>$ Rotifer $>$ Protozoa $>$ fish eggs/larvae $>$ beetle larvae/crab larvae) had earlier been observed in the segment of the river in Oyigbo LGA by Zabbey et al.,[34] and in Warri River by Egborge[23] all in the Niger Delta region of Nigeria.
The greater abundance of the rotiferan plankton biotype over some others (fish eggs and larvae, crab larvae, and beetle larvae) was most probably due to their ability to withstand and survive in varying limnological conditions prevailing at the different locations over the seasons. Some rotifers have been reported as primary consumers that feed on various phytoplankton, while others are reported as raptorial predators that feed on bacteria and detritus matter $[36$, 37].

Sampling location 1, the upstream control location that recorded the highest species abundance also experienced less human activities (sand mining only commenced here in the second year of study) than the rest of the locations due to its location in the more pristine rural community. The other locations were situated in urban areas where more anthropogenic activities are ongoing. This less human interference may have encouraged stability and growth of more plankton species in location 1.

\subsection{Biotic Diversity}

Biotic diversity was low, especially when compared with the work of Ogamba et al.[38] in Elechi Creek Complex of the Niger Delta. Zero diversities (which were also recorded for the zooplankton biotypes of the river by Zabbey et al.,[34]) were recorded at many sampling locations. However, Zabbey et al. [34] recorded mean zooplankton Margalef's diversity of 0.882 , comparable to the current study's diversity of 0.926 . This paucity could be attributed to perturbations in water column, especially from sand mining activities, which could exert selective effects on biological assemblages[39, 40]. Zabbey et al.[34] have also identified sand mining as being responsible for low plankton abundance and diversity in the Imo River, even as Tamuno[41] had also identified it as exerting deleterious effects on plankton community composition elsewhere in the Niger Delta area. Intense in-stream sand mining could cause episodic proximal turbidity as well as depletion of nutrient loads in the sediments of aquatic systems, especially on long-term basis.

The absence of beetle larvae in almost all the locations (except location 3) could be attributed to predation and competition by rotifers and fish, which are capable of excluding a particular group of organisms. However, other successional patterns have been observed by Egborge[23] in Warri River.

\subsection{Hierarchical Cluster Analysis (HCA)}

HCA is an exploratory tool that reveals natural groupings within a data set that would otherwise not be apparent. Its grouping of plankton clusters that did not depend on numerical nor apparently assumed criteria in this study confirms this. The clustering of crab larvae, fish eggs and larvae, beetle larvae and copepoda together, and the lone rotifer, cladocera and protozoa must have utilized criterion other than numerical abundance. This reveals that there are latent relationships existing between the plankton biotypes, which otherwise were not exposed by numerical abundance and 
diversity alone. This is in line with Belgrano et al.[42] observation that although non-linear density-dependence has been widely used in population dynamics studies, the existences of non-linear exogenous forces have been less explored. Therefore, the formulation of population dynamics models should include both non-linear endogenous and exogenous responses for a better understanding of the effects of natural systems in the environment.

\section{Conclusions}

Zooplankton biotypes identified were spatially dominated by the cladocerans, with beetle larvae and crab larvae as the least taxa encountered. Sampling location 1 recorded the highest plankton abundance and diversity due to its relatively pristine disposition, while location 3 recorded the least due to more anthropogenic activities there. Plankton abundance and diversity were comparatively low, with marked spatial variation. Ongoing in-stream sand mining could be associated with observed declining abundance and diversity of biotypes since this perturbation has been linked to habitat decimation and declining biodiversity elsewhere.

\section{Appendix 1}

List of zooplankton divisions and species identified in Imo River in Etche LGA (March 2007-February 2009)

\section{Cladocera}

Alonella rostrata (Koch)

Bosmina longirostris (O.E. Mūller)

Chydorus gibbus Lilljeborg

Daphnia hyalins (Leydig)

D. carinata Sars

Pleuroxus spp

\section{Copepoda}

Canthocamptus staphylinus (Jurine)

C. carinetus Shen et sung

Paracyclops finibriatus (Fischer)

Limnocalanus macrurus

Senecella calanoides Sar

\section{Other crustaceans}

Crab larvae

Pisces

Fish eggs

Fish larvae

\section{Insecta}

Beetle larvae

\section{Rotifera}

Colurella spp

Keratella valga Ehr

Branchionus forficula Wierzejski

Rotifer spp

\section{Protozoa}

Arcella arenaria Greff.

Didinium bolbianii (Fabre-Domergue)

Peridinium bipes Stein

\section{REFERENCES}

[1] Netherlands Engineering Consultants (NADECO), The waters of the Western Niger Delta, The Hague, 1961.

[2] Mogo, F.C., Assessment of heavy metals in soil, water, sediment and certain plant taxa in Imo and New Calabar Rivers, PhD Thesis, University of Port Harcourt, Nigeria, 2002.

[3] Sikoki, F.D. and Zabbey, N., Environment gradients and benthic community of the Middle Reaches of Imo River, South-Eastern Nigeria, Environment and Ecology, 24, 1, 32-36, 2006.

[4] Pringle, C, Vellidis, G, Heliotis, F and Bandacu, D, Environmental problems of the Danube Delta, American Scientist, 81, 350-361, 1993.

[5] Ellery, W. N. and McCarthy, T.S., Principles for the sustainable utilization of the Okavango Delta ecosystem, Botswana, Biological Conservation, 70, 159-168, 1994.

[6] Nwankwo, D. I., Notes on the effects of human induced stressors in parts of the Niger Delta, Nigeria, Polish Ecological Studies, 22(1-2), 71-78, 1996.

[7] Abam, T. K. S., Regional hydrological research perspectives in the Niger Delta, Hydrological Sciences, 46(1), 13-25, 2001.

[8] Ohimain, E. I., Environmental impacts of dredging in the Niger Delta, Terra et Aqua, 97, 9-19, 2004.

[9] Ohimain, E. I., Imoobe, T.O.T., and Benka-Coker, M.O., The impact of dredging on macrobenthic invertebrates in a tributary of the Warri River, Niger Delta. African Journal of Aquatic Sciences, 30(1), 49-54, 2005.

[10] Spaak, P. and Bauchrowitz, M., Environmental influences and plankton dynamics, Eawag: Swiss Federal Institute of Aquatic Science and Technology, 69e, 25-27, 2010.

[11] Ogbuagu, D.H., Chukwuocha, N.A.C., Okoli, C.G. and Njoku-Tony, R.F., Physicochemical gradients and in situ yields in pelagial primary production of the middle reaches of Imo River in Etche, South-eastern Nigeria, Journal of Ecology and the Natural Environment, 3(2), 47-53, 2011.

[12] Keller, B., Wolinska, J., Manka, M. and Spaak, P., Spatial, environmental and anthropogenic effects on the taxon composition of hybridizing Daphnia. Philosophical Transactions of the Royal Society B: Biological Sciences, 363, 2943-2952, 2008 .

[13] Shell Petroleum Development Company of Nigeria Limited (SPDC), Environmental Impact Assessment of Obigbo Node Associated Gas Gathering Project: Final Report by Tial Trade Limited, 1998.

[14] Grant, I.F., Aquatic invertebrates. In: Ecological Monitoring Methods for the Assessments of Pesticide impact in the Tropics, I.F. Grant and C.C.D. Tingle, (eds.), London: The 
University of Greenwich, p.183-193, 2002.

[15] Anene, A, Techniques in Hydrobiology: Research Techniques in Biological and Chemical Sciences, E.N. Onyeike and J.O. Osuji (eds.), Owerri: Springfield Publishers Ltd., 174-189, 2003.

[16] Boney, A.D., Phytoplankton Publication. Photo Books (Bristol) Ltd.1-82, 1983.

[17] Whitford, L.A. and Schumacher, G.J., A Manual of fresh-water algae. Sparks Press, Raleigh, 324pp, 1973.

[18] Needham, J.G. and Needham, P.R., 1974. A Guide to the study of freshwater Biology, Holde-Day Publishers, San Francisco.

[19] Cole, A, A Text Book of Limnology. London: Longman, 426pp, 1978.

[20] Maosen, H, Illustration of Freshwater Plankton. Agricultural Press, 171pp, 1978.

[21] Jeje, C.Y. and Fernando, C.H., A practical guide to the identification of Nigerian zooplankton (Cladocera, copepoda and rotifera), Kainji Lake Research Institute, 1986.

[22] Jeje, C.Y. and Fernando, C.H., An illustrated guide to identification of Nigerian freshwater rotifers, Nigerian Journal of Science, 25, 77-95, 1991.

[23] Egborge, A.B.M., Water Pollution in Nigeria Vol. 1: Biodiversity and Chemistry of Warri River, Ben Miller Books Nig. Ltd., 313pp, 1994.

[24] American Public Health Association (APHA), Standard Methods for the Examination of Water and Wastewater, $20^{\text {th }}$ ed. APHA/AWWA/WEF: Washington DC, 1998.

[25] Margalef, R., Communication of structure in plankton population, Limnology and Oceanography, 6, 124-128, 1961.

[26] Eze, V.C., Aspects of the Ecodynamics of a Niger Delta river receiving industrial effluents, $\mathrm{PhD}$ Thesis, University of Port Harcourt, .xv+256pp, 2005.

[27] Chattopadhyay, C., Barik, A., The composition and diversity of net zooplankton species in a tropical freshwater lake, International Journal of Lakes and Rivers, 2(1), 21-30, 2009.

[28] Altaf, H.G., Saltanat, P., Asif, A.K. and Maryam, H, Phytoplankton diversity at Watlab Ghat in Wular Lake, Kashmir, Journal of Ecology and the Natural Environment, 2(8), 140-146, 2010.

[29] Rai, A, Morthy, K.S.V. and Reddy, H.R.V., Phytoplankton and Hydrography in the Coastal Waters of Thannirbhavi,
Southwest Coast of India, Environment and Ecology, 24(2), 449-456, 2006.

[30] Armitage, P.D., Moss, D, Wright, J.F. and Furse, M.T., The performance of a new biological water quality score system based on macroinvertebrates over a wide range of unpolluted running water sites, Water Research, 17, 333-347, 1983.

[31] Armitage, P.D., Gunn, R.J.M., Furse, M.T., Wright, J.F. and Moss, D, The use of prediction to assess macroinvertebrate response to river regulation, Hydrobiologia, 14, 25-32, 1987.

[32] Ogwejiofor, G.C., Counting the cost of gas flaring and venting for enhanced gas resource management in Nigeria, A paper delivered in a government forum on environmental degradation in Nigeria, Abuja, 2000.

[33] United States Environmental Protection Agency (EPA), Effects of Acid Rain, 2003.

[34] Zabbey, N., Sikoki, F.D. and Edoghotu, J, Plankton assemblages and environmental gradients in the Middle Reaches of the Imo River, Niger Delta, Nigeria, African Journal of Aquatic Science, 33(2), 241-248, 2008.

[35] Okogwu, O.I. and Ugwumba, O.A., The zooplankton and environmental characteristics of Ologe Lagoon, South West Nigeria, The Zoologist, 1 (4), 86-92, 2006.

[36] Boulin, V.V., Nikulina, V.N., Paveljeva, E.B. and Stepanova, L.A., Microbial loop in trophic food web of lake plankton, Journal of General Biology, 60, 431-444, 1999.

[37] Hakanson, L, Boulin, V.V. and Ostapenia, A, The influence of biomanipulations (fish removal) on the structure of lake food web, case studies using Lake Web-model, Aquatic Ecology, 37, 47-68, 2003.

[38] Ogamba, E.N., Chindah, A.C., Ekweozor, I.K.E. and Onwuteaka, J.N., Water quality and phytoplankton distribution in Elechi Creek Complex of the Niger Delta, Journal of Nigerian Environmental Society (JNES), 2(2), 121-130, 2004.

[39] Bilgrami, K.S. and Saha, L.C., A Textbook of Algae, India: CBS Publishers and Distributors, 13-212, 1992.

[40] GEASAMP, Biological indicators and their use in the measurement of condition of marine environment, GESAMP Rep. Studies, 55, 4-2, 1995.

[41] Tamuno, P.B.L., Eco-livelihood assessment of inland river dredging: the Kolo and Otuoke creeks, Nigeria, a case study, PhD Thesis, Loughbourogh University.xx+351pp, 2005.

[42] Belgrano, A., Lima, M. and Stensseth, N.C., Non-linear dynamics in marine phytoplankton population systems, Marine Ecology Progress Series MEPS, 273, 281-289, 2004. 